\title{
Mengatasi Distorsi Kognisi pada Remaja
}

\author{
Camelia Kristika Pepe dan Meilanny Budiarti Santoso
}

\begin{abstract}
Teenager is one of the phase that will be experienced in by all of an adult human being. The failure in meet the needs and the development of duty during adolescence can become difficulties to have a self actualization. The difficulties' symptoms can be started from the appearance of thought and selftalk negative on theirselves. It is known with the term cognitive distortion. The distortion is cognitive deviation the thought that is experienced by individuals. Deviation this thinking consist of personalization, over generalization, mental filter, mind reading, development with equity should the statement and also minimization. Social workers as a profession assistance having stage practices to do and starting from initial phase namely assessment into termination. In the case of clients by distortion cognitive, social workers may provide various technique therapy to change the mind automatic (selftalk) for client from negative to be positive selftalk. One technique therapy which could be provided by a social worker in clients by distortion cognitive is therapeutic cognitive three colom. This therapy is intended to transform the mind clients which was originally irrational being rational, reduce their negative thoughts and change dysfunctional thought process. When social workers use this therapy in help clients the clients should make self report which serves to see the replacement of irrational thought after they have been given the therapy.
\end{abstract}

Keywords: Distorsi Kognitif, Selftalk, Kognitif Tiga Kolom.

\section{Pendahuluan}

Manusia sebagai mahkluk sosial dalam kehidupannya tentulah memiliki kekurangan dan kelebihan. Sebagaimana hakekatnya manusia secara individu saling berada untuk melengkapi kekurangan yang dimiliki oleh satu individu dengan individu lainnya. Beragam jenis permasalahan klien yang dapat menjadi kasus yang harus ditangani oleh seorang pekerja sosial, salah satunya adalah klien yang memiliki masalah dalam melihat dirinya (distorsi kognitif). Gejala yang muncul dapat berupa keadaan di mana klien menyadari seringkali dirinya bersikap skeptis dimana ia merasa apa yang dilakukannya akan ditentang oleh banyak orang dan klien tidak mau keluar dari zona nyamannya meskipun klien sebenarnya sudah mengetahui langkah apa yang harus diambilnya ketika ia menghadapi situasi tersebut.

\section{Pembahasan}

\section{Gambaran umum situasi klien dengan distorsi kognitif}

Berikut akan dipaparkan gambaran umum situasi klien dengan distorsi kognitif berupa mind reading, personalization dan must statement yang diperoleh mahasiswa praktikan berdasarkan hasil assessment dalam proses pendampingan terhadap klien.

Klien selalu merasa dihempaskan dari lingkungan sekitarnya baik keluarga maupun teman sepermainan karena klien dipandang bodoh dan malas. Pernyataan lingkungan yang demikian terhadap klien seolah mendoktrin diri klien sehingga hal ini berdampak pada pola pikir klien. Selain itu juga klien memiliki sikap yang sedikit introvert (menutup diri). Di dalam keluarga, klien jarang melakukan komunikasi yang intim. Klien hanya berbicara jika ditanya, dan situasi tersebut menjadi suatu bumerang pada diri klien sendiri. Klien merasa kurang mendapatkan perhatian dari orang tu- 
anya, namun karena memiliki sifat seperti yang telah digambarkan di atas, maka hal tersebut membuat klien menjadi sulit untuk membuat keadaannya seperti apa yang diinginkannya.

Klien tidak menyadari pangkal masalah yang dihadapinya. Hasil assessment menunjukkan bahwa permasalahan klien diawali dari banyaknya pikiran negatif terhadap diri klien sendiri maupun keadaan lingkungan sekitarnya. Dapat dikerucutkan bahawasanya klien mengalami masalah distorsi kognitif pada mind reading, personalization dan must statement. Klien seringkali merasa seolah-olah ia tahu akan apa yang dipikirkan orang lain terhadap dirinnya dan cenderung negatif. Selain itu sering muncul dalam pikiran klien untuk menyalahkan dirinya sendiri atas peristiwa yang terjadi bahkan klien sempat merasa dirinya sebagai orang yang paling bersalah atas kondisi keluarganya yang banyak menuntut pada diri klien. Pernyataan harus melakukan sesuatu seringkali muncul dalam pikiran klien. Klien merasa bahwa segala pernyataan yang diberikan orang lain terutama keluarganya adalah sesuatu yang harus dipenuhi sehingga klien tidak memiliki kebebasan untuk bertindak.

Klien memiliki cita-cita yang juga menjadi tuntutan keluarganya, agar klien mendapatkan beasiswa master di luar negeri. Dengan menghadapi tuntutan tersebut, klien baru tersadar pada masalah dirinya, bahwa ia menjadi tidak percaya diri dan menjadi malas untuk melakukan segala usaha untuk mendapatkan beasiswa master di luar negeri tersebut. Setiap kali klien yakin dengan keputusannya untuk mendapatkan beasiswa master di luar negeri dan ingin berubah menjadi pribadi yang lebih rajin, klien seolah takut dan berprasangka negatif terhadap usahanya sendiri, seperti: pasti usaha itu akan gagal karena klien bodoh, pasti akan ditertawakan orang lain, pasti tidak ada pihak yang menstimulus positif dirinya dan berbagai prasangka negatif lainnya. Hal ini menjadi penting untuk digarisbawahi, karena dengan munculnya pikiran otomatis (selftalk) klien yang sifatnya negatif tersebut dirasa sangat mengganggu bagi klien sehingga perlu diubah melalui proses pertolongan pekerjaan sosial yang dilakukan oleh pekerja sosial.

\section{Tinjauan Mengenai Gangguan Kognitif}

Gangguan kognitif atau yang lebih dikenal dengan distorsi kognitif (Burns, 1988) adalah sesuatu yang dapat dialami oleh individu terdiri dari penyimpangan pemikiran-pemikiran, antara lain berupa: personalization, over generalization, filter mental, mind reading, must statement, minimization dan lain sebagainya. Secara khusus, pikiran otomatis individu secara tidak sadar berpengaruh dalam proses pengembangan kepribadian. Pikiran seperti itu merupakan aspek kognitif yang penting dalam memahami bagaimana individu membuat pilihan dan menarik kesimpulan yang ada di dalam pikirannya.

Pikiran-pikiran individu yang terdistorsi akan dapat berdampak pada kepribadian individu itu sendiri sehingga diperlukan terapi untuk mengurangi dan merubah distorsi negatif tersebut. Peranan terapi kognitif dalam hal ini adalah sebagai proses berpikir dan perubahan dalam tingkah laku serta berfokus pada masalah maupun tujuan yang ingin dicapai.

Penggunaan terapi kognitif dalam kasus distorsi kognitif adalah untuk membantu klien mengubah pernyataan negatif menjadi positif dalam pikirannya. Pendekatan kognitif ini berguna untuk mengubah pikiran-pikiran otomatis (selftalk) dan skema kognitif. Untuk mengubah pikiran otomatis (selftalk) negatif dan irasional yang dialami klien dapat digunakan terapi kognisi tiga kolom dimana terapi ini dapat membantu klien agar dapat mengubah pikiran otomatisnya (selftal-nya) menjadi pikiran yang positif dan rasional. 
Kondisi kognitif klien tentunya dipengaruhi oleh perkembangan psikososial yang dialaminya. Perkembangan ini akan menunjukkan sedang dalam tahap apa kondisi klien. Salah satu teori psikososial yang dapat digunakan untuk menganalisa kondisi perkembangan psikososial adalah seperti yang dikemukakan oleh Erik Erikson. Teori psikososial Erikson merupakan bentuk pengembangan dari teori psikoseksual yang dikemukakan oleh Sigmund Freud. Erikson membagi tahapan perkembangan psikososial menjadi delapan tahapan perkembangan seperti berikut:

Tabel 1

Tahapan Perkembangan Psikososial Erikson

\begin{tabular}{|c|l|l|}
\hline Tahap & \multicolumn{1}{|c|}{ Perkiraan Usia } & \multicolumn{1}{|c|}{ Krisis Psikososial } \\
\hline I & Lahir -18 bulan & $\begin{array}{l}\text { Trust vs Mistrust } \\
\text { (percaya vs tidak percaya) }\end{array}$ \\
\hline II & 18 bulan -3 tahun & $\begin{array}{l}\text { Autonomy vs Doubt } \\
\text { (kemandirian vs keraguan) }\end{array}$ \\
\hline III & 3 tahun -6 tahun & $\begin{array}{l}\text { Initiative vs Guilt } \\
\text { (inisiatif vs rasa bersalah) }\end{array}$ \\
\hline IV & 6 tahun -12 tahun & $\begin{array}{l}\text { Industry vs Inferiority } \\
\text { (ketekunan vs rasa rendah diri) }\end{array}$ \\
\hline V & 12 tahun -20 tahun & $\begin{array}{l}\text { Identity vs Role Confusion } \\
\text { (identitas vs kekacauan identitas) }\end{array}$ \\
\hline VI & $\begin{array}{l}\text { Dewasa awal }( \pm 20 \text { tahun }-40 \\
\text { tahun) }\end{array}$ & $\begin{array}{l}\text { Intimacy vs Isolation } \\
\text { (keintiman vs isolasi) }\end{array}$ \\
\hline VIII & $\begin{array}{l}\text { Dewasa pertengahan }( \pm 40 \text { tahun }- \\
\text { Dewasa akhir / tua }( \pm 65 \text { ke atas) }\end{array}$ & $\begin{array}{l}\text { Generativity vs Self Absorption } \\
\text { (generativitas vs stagnasi) }\end{array}$ \\
\hline
\end{tabular}

Sumber: Cramer, Craig, Flynn, Bernadette. \& LaFave, Ann. 1997. Critiques \& Controversies of Erikson

Teori perkembangan psikososial berlaku secara berurutan tahap demi tahap sesuai dengan tahapan perkembangan usia manusia. Menurut teori perkembangan psikososial Erikson, apabila seseorang terlambat mengenal jati dirinya, hal tersebut disebabkan oleh kegagalan orang tersebut dalam proses perkembangan psikososial tahap sebelumnya. Bagi mereka yang tidak yakin terhadap kepercayaan diri dan keputusannya maka akan muncul rasa tidak aman dan bingung terhadap diri serta masa depannya.

Metode dan teknik terapi dari teori kognitif dapat digambarkan secara sederhana dan jelas. Dalam prosesnya, pekerja sosial berorientasi kognitif berdasarkan kegiatan yang dilakukannya:

1. Perubahan persepsi mengubah emosi, motif (tujuan) dan perilaku

2. Perubahan dalam tujuan sangat berpengaruh dalam perilaku

3. Kegiatan baru dan jenis baru dari perilaku mengubah persepsi

Dengan demikian, teknik terapi kognisi tiga kolom akan mempengaruhi kondisi kognitif, sikap dan perilaku dari klien yang bersangkutan. Terapi Kognisi Tiga Kolom diberikan kepada klien dengan memberikan pikiran-pikiran otomatis (selftalk) dengan cara klien diminta untuk mengisi bentuk distorsi kognitifnya lalu mengisi kolom tanggapan rasionalnya yang muncul. 


\section{Pembahasan Kasus; Remaja dengan distorsi kognisi (mind reading, personalization dan must statement)}

Berikut ini akan dipaparkan proses pertolongan pekerjaan sosial terhadap klien yang mengalami distorsi kognitif berupa mind reading, personalization dan must statement dengan menggunakan terapi kognisi tiga kolom.

Teori perkembangan psikososial yang dikemukakan oleh Erikson, digunakan untuk melihat perkembangan psikis klien dan fase apa yang sedang dialaminya. Klien berada pada tahap ke-lima (usia 12-20 tahun) dengan kondisi krisis psikososial identity vs role confusion (identitas vs kekacauan identitas). Pada tahap ini sewajarnya remaja dihadapkan dengan penemuan jati dirinya yang dapat diuraikan pada proses pencarian hal-hal sebagai berikut: siapa diri mereka, bagaimana mereka nantinya dan kemana mereka menuju tujuannya dalam kehidupan serta mulai mengeksplorasi terhadap banyak hal dan membangun kepekaan dirinya.

Berdasarkan uraian di atas, kondisi klien sedang berada dalam tahap pencarian jati diri sehingga klien selalu merasa membutuhkan figur ideal yang dapat diteladaninya. Teori perkembangan prikososial menyatakan apabila seseorang terlambat mengenal jati dirinya, maka hal ini menunjukkan bahwa ia gagal dalam proses perkembangan psikososial tahap sebelumnya. Pada diri klien, kondisi tersebut semakin buruk dengan banyaknya intervensi dari luar diri klien, terutama terkait dengan harus menjadi apakah klien selepas meraih gelar sarjana.

Klien pun menyatakan bahwa dirinya selalu merasakan munculnya pikiran negatif yang menyebabkan seolah klien tahu apa yang dipikirkan oleh orang lain (mind reading), pernyataan "bodoh" dan menyalahkan diri sendiri atas keadaan yang ada membuat klien terhambat untuk dapat beraktualisasi diri. Bagi yang tidak yakin terhadap kepercayaan diri dan keputusannya maka akan muncul rasa tidak aman dan bingung terhadap diri serta masa depannya seperti yang dialami oleh klien.

Adapun ganguan kognitif yang dialami klien merupakan bentuk gagalnya selftalk positif dari dalam diri klien dalam menstimulus pikirannya sehingga menghasilkan pemikiran yang positif pula. Terapi kognitif tiga kolom digunakan untuk membantu klien mengubah mind reading, personalization dan must statementnya menjadi rasional sehingga memantapkan langkah klien dalam mencapai harapan keluarga. Terapi ini juga diperuntukan sebagai penguat perilaku klien setelah program pendampingan oleh pekerja sosial selesai dilakukan.

Berdasarkan hasil assessment yang dilakukan terhadap klien, faktor lingkungan mempengaruhi pola pikir dan perilaku klien. Dari hasil ecomap klien banyak menuturkan bagaimana temanteman kuliah klien mempengaruhi kehidupan klien seperti berpengaruh dalam gaya hidup (menjadi boros) dan membuat klien seringkali semakin merasa bodoh meskipun ejekan yang diberikan temen-temannya hanyalah candaan semata. Keluarga memegang peran penting bagi klien meskipun banyak intervensi yang dilakukan keluarga terhadap diri klien, namun bagi klien, keluarga merupakan orang-orang yang dapat dipercaya untuk kebaikan hidup diri klien sendiri.

Klien merasa tidak ada lagi lingkungan yang memberikan dukungan agar dirinya bisa berubah. Klien merasa dirinya dituntut untuk mencapai tujuan yang diinginkan orang lain tanpa tahu bagaimana proses menjalani dan melalui berbagai tuntutan tersebut. Hal tersebut berdampak pada munculnya pikiran negatif dalam diri klien yang seolah menjustifikasi bahwa klienlah yang patut disalahkan atas kondisi yang terjadi (karena kondisi orangtua yang bercerai, maka keberadaan klien menjadi harapan tunggal bagi keluarga). Klien merupakan anak yang bodoh sehingga sering dice- 
mooh sehingga klien merasa sepi dalam hidupnya karena klien merasa lingkungan sekitarnya tidak ada yang mendukungnya.

Hasil assessment menunjukkan bahwa klien memiliki masalah berupa distorsi kognitifnya, yaitu berupa banyaknya pikiran negatif yang timbul dan dirasakan sangat mengganggu aktivitas kesehariannya, terutama dalam kaitannya dengan upaya mewujudkan cita-cita klien dalam memperoleh beasiswa master ke luar negeri. Klien mudah merasa minder dan kadang menyalahkan diri sendiri. Dalam distorsi kognitif, hal-hal yang dialami klien termasuk dalam kategori personalization. Klien juga suka menebak-nebak apa yang akan dilakukan oleh orang lain terhadap dirinya dan berpikiran negatif dengan apa yang akan orang lain komentari atas perilakunya. Klien juga menceritakan bahwa saat ia bertemu dengan orang lain yang belum pernah ia jumpai sebelumnya, klien sering kali menduga-duga bagaimana sifat orang tersebut. Dalam distorsi kognitif, hal demikian termasuk dalam mind reading. Klien juga suka merasa orang-orang disekitarnya tidak bisa mengerti dan berperilaku seperti apa yang ia harapkan, sehingga hal tersebut membuat klien menjadi pribadi yang tertutup. Dalam distorsi kognitif, situasi demikian tergolong pada must statement.

Pada klien dengan distorsi kognitif, teknik cognitive restructuring berupa terapi kognitif tiga kolom dapat digunakan untuk mengatasi pikiran otomatis yang bersifat negatif dan menjadi boomerang bagi diri klien sendiri. Terapi ini bertujuan untuk mengubah pikiran irasional klien agar menjadi pikiran yang rasional, mengurangi pikiran-pikiran negatif, serta mengubah proses berpikir disfungsional yang terjadi.

Dalam melakukan terapi kognisi tiga kolom, pertama-tama dibuat pernyataan atas pikiran otomatis klien berdasarkan cerita yang sudah disampaikan klien. Setting pernyataan yang dipilih ialah berdasarkan kondisi yang paling sering mengganggu pemikiran klien seperti; banyaknya intervensi dari pihak luar tentang harus menjadi apa diri klien, rasa kesepian yang dialami klien dan juga kondisi klien yang berburuk sangka terhadap orang yang tidak dipercayainya. Kemudian form tersebut akan diberikan kepada klien untuk dilengkapi dengan pernyataan dan tanggapan klien atas situasi yang terjadi. Selama mengerjakan form tersebut klien didampingi oleh praktikan sambil menggambarkan situasional yang terjadi jika klien kurang paham.

Berikut adalah beberapa pernyataan klien sebagai contoh dari hasil pengisian form terapi tiga kolom yang dilakukan oleh klien:

Tabel 2

Treatment Terapi Kognisi Tiga Kolom

\begin{tabular}{|l|l|l|}
\hline \multicolumn{1}{|c|}{ Pikiran Otomatis } & Distorsi Kognitif & \multicolumn{1}{c|}{ Tanggapan Rasional } \\
\hline $\begin{array}{l}\text { Saya rasa jika saya mengambil tindakan } \\
\text { ini pasti orang lain akan menghujat saya, } \\
\text { karena saya memang bodoh }\end{array}$ & Mind reading & $\begin{array}{l}\text { Saya harus berubah walupun } \\
\text { sulit, demi masa depan yang } \\
\text { lebih baik }\end{array}$ \\
\hline $\begin{array}{l}\text { Apa yang dibicarakan mama saya benar, } \\
\text { saya masih muda dan tidak mengerti } \\
\text { apa-apa, saya merasa bodoh sudah me- } \\
\text { nolaknya }\end{array}$ & Personalization & $\begin{array}{l}\text { Saya lebih bisa menentukan apa } \\
\text { yang terbaik untuk saya kede- } \\
\text { pannya }\end{array}$ \\
\hline
\end{tabular}




\begin{tabular}{|c|c|c|}
\hline $\begin{array}{l}\text { Aku harus khawatir terhadap hal-hal } \\
\text { yang dapat membahayakan, tidak } \\
\text { menyenangkan atau menakutkan. Jika } \\
\text { aku tidak mengkhawatirkannya aku takut } \\
\text { hal-hal itu terjadi }\end{array}$ & Must statement & $\begin{array}{l}\text { Banyak yang peduli dan sayang } \\
\text { sama saya sehingga mereka } \\
\text { dapat membantu saya untuk } \\
\text { merundingkan masa depan atau } \\
\text { pilihan terbaik }\end{array}$ \\
\hline
\end{tabular}

Sumber: Praktikum Mikro, 2015

Pada pernyataan pertama "Saya rasa jika saya mengambil tindakan ini pasti orang akan menghujat saya karena saya memang bodoh" merupakan pemikiran otomatis yang muncul dari diri klien karena klien merasa apa yang akan dilakukannya selalu dicemooh orang lain, terutama teman-temannya. Misalnya saja saat klien mengemukakan niatnya untuk belajar lebih giat dan mengurangi waktu bermainnya demi mendapatkan beasiswa ke luar negeri, teman-teman klien justru mentertawakannya meskipun hanya sebuah candaan. Klien merespon pemikiran negatif tersebut dengan pernyataan rasional berupa "saya harus berubah walupun sulit, demi masa depan yang lebih baik". Pernyataan tersebut bagi klien memang sulit untuk diterapkan. Klien mengakui bahwa dirinya sadar terhadap pemikiran tersebut, namun pernyataan negatif dalam diri klien yang seolah mengetahui apa yang dipikirkan oleh orang lain memiliki porsi lebih besar dalam diri klien sehingga lebih menguasai cara berpikirnya. Rasionalisasi yang dilakukan oleh klien yaitu ia merasa bahwa untuk berubah memang sulit dan pasti akan menuai banyak respon dari orang-orang sekitarnya. Pikiran rasional klien pun mengatakan bahwa jika ia tidak belajar untuk melalui hal tersebut, maka cita-citanya tidak akan pernah tercapai.

Pemikiran otomatis yang kedua yaitu "apa yang dibicarakan mama saya benar, saya masih muda tidak mengerti apa-apa, saya merasa bodoh sudah menolaknya". Klien mencoba mengubah pemikiran ini dengan "saya lebih bisa menentukan apa yang terbaik untuk saya kedepannya". Menurut klien selama ini ketika ia ingin menolak sesuatu yang diperintahkan oleh orang lain kepadanya, klien merasa tidak enak hati, terlebih apabila yang menyuruhnya adalah keluarganya. Klien sebenarnya menyadari kapasitas dirinya yang belum mampu untuk mewujudkan harapan keluarga untuk mendapatkan beasiswa di luar negeri. Oleh karena itu, klien merasa bersalah kepada keluarganya. Klien merasa bodoh karena belum mampu menyanggupi dan berusaha mewujudkan harapan keluarganya tersebut. Rasionalisasi yang klien jelaskan saat mengubah pernyataan irasionalnya adalah pada situasi ini klien memahami sejujurnya yang tahu kapasitas dirinya adalah diri klien sendiri sehingga saat orang lain berkata demikian, mereka itu hanya sekedar mengingatkan saja dan selebihnya diri klien sendiri yang tahu apa yang terbaik.

Pemikiran otomatis ketiga yaitu: "Aku harus khawatir terhadap hal-hal yang dapat membahayakan, tidak menyenangkan atau menakutkan. Jika aku tidak mengkhawatirkannya aku takut hal-hal itu terjadi”. Pemikiran ini disadari klien sering timbul akibat klien merasa semua orang berpikiran negatif terhadap apa yang dilakukannya. Misalnya saja saat klien memutuskan untuk menuruti kemauan keluarganya mendapatkan beasiswa master. Klien menceritakan hal tersebut pada teman-temannya namun ia tidak merasa mendapat dukungan apapun. Semenjak itu klien merasa dirinya diacuhkan dan justru kehadiran teman-temannya ini menjerumuskan klien agar ia tidak mencapai cita-citanya dengan sering mengajaknya bermain ke mall bukan mengajaknya belajar bersama. Klien memilih untuk menutup diri sementara waktu karena pikiran tersebut. Klien be- 
randai-anadai bahwa segala sesuatu yang menurutnya negatif harus dikhawatirkan. Klien mencoba mengubah pernyataan tersebut dengan "banyak yang peduli dan sayang sama saya sehingga mereka dapat membantu saya untuk merundingkan masa depan atau pilihan terbaik".

Berdasarkan hasil pengisian form terapi tiga kolom tersebut di atas, klien menyadari pikiran rasional apa yang seharusnya muncul ketika dirinya menghadapi sebuah situasi. Klienpun paham bawa distorsi kognitif mengganggu dirinya dalam beraktivitas terutama saat klien ingin mengambil keputusan tertentu. Dari hasil treatment ini praktikan mengajak klien untuk membuat self report setiap harinya selama satu minggu setelah pengisian form 3 kolom. Self report ini berfungsi untuk melihat adakah pemikiran rasional yang menggantikan pemikiran irasional klien berdasarkan situasi yang ia alami sehari-hari.

Berdasarkan self report yang klien tuliskan setiap hari selama satu minggu, menunjukkan bahwa klien sesudah mulai dapat mengontrol dirinya. Klien yang awalnya merasa menjadi orang yang paling tertekan baik di dalam keluarga maupun ketika bersama teman-temannya, kini mulai berani dalam mengambil sikap. Saat membuat self report selama seminggu, klien memang tidak banyak menemui situasi yang mengarahkannya untuk kembali berpikiran negatif dan sesekali saat pikiran negatif akan muncul, klien mencoba untuk menahan dirinya dengan berpikir "banyak yang peduli dan sayang sama saya sehingga mereka berkata seperti itu". Klien merasa semua orang memang ditakdirkan untuk berbeda karenanya jika ada yang mencemooh dirinya, klien menganggap hal ini sebagai wahana belajar dan juga pacuan untuk berusaha lebih giat lagi agar cita-citanya untuk mendapat beasiswa bukan lagi hanya sekedar wacana saja.

Akan tetapi masih ada target yang masih belum terlaksanakan dengan maksimal yaitu mengurangi atau menghilangkan mind reading pada klien. Klien mengakui sulit untuk tidak berprasangka buruk terhadap apa yang akan orang lain katakan ketika klien mengambil suatu tindakan. Langkah konkret yang akan diambil setelah proses pendampingan ini selesai adalah klien akan berusaha memfilter pikiran yang ada dan berusaha menahan diri sehingga tidak terus menerus merasa tertekan dan bodoh. Klien juga bertekad untuk membaca buku minimal satu jam seharinya demi menambah pengetahuannya untuk dapat meraih beasiswa master di luar negeri.

\section{Simpulan}

Remaja seringkali mengalami masalah dalam aktualisasi dirinya termasuk kesalahan pemikiran yang dikenal dengan distrosi kognitif. Dalam masalah ini klien yang ditangani seolah-olah mengetahui apa yang orang lain pikirkan terhadapnya (mind reading) hal ini biasanya muncul saat klien melakukan sebuah tindakan yang berhubungan dengan banyak orang. Permasalahan perzonalization muncul saat klien banyak menerima tekanan dari keluarga terutama tuntutan keluarga yang memaksanya mendapatkan beasiswa studi master ke luar negeri. Sedangkan permasalahan must statement mucul ketika klien menghadapi situasi yang tidak sesuai dengan harapannya. Contohnya saat klien bercerita kepada teman gank tentang niatannya belajar demi menggapai cita-cita mendapat beasiswa studi master. Klien mendapat cemoohan dari teman-temannya dan hal ini membuat klien menjadi pribadi yang tertutup.

Masalah kognitif ini sebenarnya disadari klien sebagai hal yang paling mengganggu terutama saat ia hendak mengambil sebuah keputusan. Namun klien baru benar-benar merasakannya ketika klien dihadapkan pada tuntutan keluarga untuk melanjutkan studi master ke luar negeri den- 
gan beasiswa. Klien merasa takut, minder, tidak didukung dan kesepian selama menjalankan usaha untuk menggapai cita-citanya tersebut. Dalam menggali informasi dari klien, proses assessment dilakukan dengan menggunakan instrumen genogram, ecomap dan instrumen assessment keberfungsian sosial klien.

Terapi dilakukan dengan menggunakan terapi tiga kolom. Terapi ini harus dijelaskan secara detil agar klien tidak berpikiran kalau terapi ini hanya mengerjakan pernyataan negatif menjadi pernyataan positif saja. Lebih dari itu, terapi tiga kolom bisa efektif apabila diterapkan tidak hanya saat mengerjakannya tetapi saat menjalani kehidupan juga dan harus ada monitoring setelah pengisian treatment tersebut. 


\section{Bibliografi}

Calvin S. Hall \& Gardner Lindzey. Psikologi Kepribadian 1, Teori-Teori Psikodinamik (Klinis). Yogyakarta: Kanisius. 1993

Payne, Malcolm. Modern Social Work Theory Second Edition. London: Macmillan Press. 1997

Soekanto, Soerjono. Sosiologi Suatu Pengantar. Jakarta : Raja Grafindo Persada. 1990

Turner, Francis Joseph. Social Work Treatment. New York: Third Avenue. 1979

Wibhawa, Budhi, Santoso Tri Raharjo, Meilanny Budiarti. Dasar-Dasar Pengantar Pekerjaan Sosial. Bandung: Widya Padjadjaran. 2010 